\title{
Sistem Informasi Akademik Berbasis Teknologi Barcode dan Webcam Studi Kasus SMA N 1 Singaraja
}

\author{
Kadek Surya Mahedy \\ Jurusan Manajemen Informatika, FTK, Undiksha
}

\begin{abstract}
ABSTRAK
Sekarang ini sistem Akademik pada sebuah sekolah sudah wajib ada, karena laporan hasil belajar sudah seperti transkrip nilai di perguruan tinggi, selain itu proses pengarsipan data secara terpusat juga sangat diperlukan untuk mempermudah proses pencarian data. Untuk meningkatkan manfaatnya, data harus dicatat secara sistematis, diringkas dan dikelompokkan, serta disajikan dalam laporan. Pengarsipan data secara manual masih menjadi kendala untuk mendapatkan hasil pencatatan yang baik karena kesalahan-kesalahan dalam pencatatan data sering terjadi serta waktu yang diperlukan untuk mendapatkan suatu laporan cukup lama. Pada penelitian ini akan dibuat sebuah sistem informasi akademik yang berguna untuk mengatasi kendala-kendala pada proses pengarsian data yang dilakukan secara manual. Sistem ini merupakan sistem yang mudah digunakan, karena pemakai sistem ini tidak memerlukan keahlian khusus dalam bidang akademik untuk dapat mengoperasikannya karena sebagian besar tugastugas dikerjakan oleh sistem secara otomatis, mulai dari proses pencarian data-data sampai memproses laporan-laporan. Sistem informasi ini dibangun dengan bahasa Visual Basic 6.0 dan database menggunakan Sql server 2000.

Kata-kata kunci : Barcode, Webcam. Akademik
\end{abstract}

\section{ABSTRACT}

Nowadays, academic system has an important role ini education. It must be had by every school, because the report of learning result are similar with academic transcript at Academic Institution. Besides, the process of filling data centralized is also needed in order to find the data easier. To improve its benefit, the data must be written systematically, summarized and categorized, and also presented in report. Filling the data manually still become problem to get good result, because there are many errors in recording the data and taking long time to get report. This study will make an academic information system which is useful to overcome the problem in the process of filling data manually. This system is an easy system because the user of the system don't need specific skill in academic fields to operate it, because the major tasks are done by the system automatically such as: the process of finding data until processing the report. This information system is built by visual basic 6.0 and database language using SQL server 2000.

Keyword: Barcode, Webcam. Akademik.

Sistem Informasi Akademik Berbasis Teknologi Barcode..........(Kadek Surya Mahedy) 


\section{PENDAHULUAN}

Istilah TI (Teknologi Informasi) atau IT (Information Technology) yang populer saat ini adalah bagian dari perkembangan istilah dalam dunia SI (Sistem Informasi) atau IS (Information System). Istilah TI memang lebih mengacu pada teknologi yang digunakan dalam menyampaikan maupun mengolah informasi, namun pada dasarnya masih merupakan bagian dari sebuah sistem informasi itu sendiri (kadir, 2003). TI memang lebih mudah dipahami secara umum sebagai pengolahan informasi yang berbasis pada teknologi komputer yang saat ini sedang berkembang pesat. Sebuah Sistem Teknologi Informasi (STI) dibangun oleh konsep dasar yang memberikan pemahaman yang penting dan menyeluruh dari sebuah STI yang sedang dibangun. Setidaknya STI yang dibangun nantinya dapat memberikan informasi sesuai dengan yang diinginkan. Informasi yang dihasilkan hendaknya sesuai dengan pemahaman dan berguna saat proses penerapan STI dengan aplikasinya. Sistem Teknologi Informasi dapat dikembangkan dengan teknologi komputer, telekomunikasi maupun teknologi lain yang dapat memberi nilai tambah dalam proses Informasi. Proses pengaplikasian dari STI dapat diterapkan dengan berbagai cara. Salah satu cara yang dapat dilakukan dengan mengikuti fungsi-fungsi organisasi atau tingkatan manajemen dimana STI tersebut akan diaplikasikan.

STI yang diaplikasikan mengikuti fungsi-fungsi organisasi yang ada misalnya, MIS (Marketing Information System) untuk Bagian Penjualan, HRIS (Human Resources Information System) untuk Bagian Personalia, atau FIS (Financial Information System) untuk Bagian Keuangan. Sedangkan STI yang diaplikasikan mengikuti fungsi-fungsi manajemen yang ada misalnya, TP (Transaction Processing) dan PCS (Process Control System) untuk manajemen level bawah, DSS (Decision Support System) atau sistem penunjang keputusan, ES (Expert System) atau System pakar, EIS (Executive Information System) untuk manajemen tingkat menengah dan atas.

SMA Negeri 1 Singaraja merupakan salah satu sekolah unggulan yang ada di Kabupaten Buleleng. Akan tetapi SMA Negeri 1 Singaraja sampai saat ini belum memiliki sebuah sistem informasi, baik sistem informasi administrasi ataupun sistem informasi akademik sehingga proses administrasi dan akademik masih dilakukan 
dengan cara manual, proses-proses yang dilakukan dengan cara manual tersebut adalah sebagai berikut:

1. Proses entry data siswa belum memanfaatkan sistem informasi, masih menggunakan Microsoft Ecxel sehingga proses pencarian data siswa relatif lama, selain itu juga akan mempersulit proses pengarsipan data siswa.

2. Kartu siswa belum terintegrasi dengan sistem Barcode dan web camera (untuk mengambil foto langsung tanpa harus menyerahkan foto)

3. Proses pembayaran SPP masih dilakukan dengan cara manual

4. Proses pencetakan laporan hasil belajar relatif lambat karena belum memanfaatkan Sistem Informasi.

Berdasarkan kelemahan-kelemahan dari sistem akademik yang dilakukan dengan cara manual diatas, maka dipandang perlu untuk mengembangkan sebuah Sistem Informasi Akademik Berbasis Teknologi Barcode dan Webcam. Sistem Barcode dan Webcam akan diaplikasikan saat pembuatan kartu siswa, sehingga pada kartu siswa terdapat Barcode sesuai dengan nomor induk siswa yang bersangkutan, yang nantinya akan mempermudah proses pembayaran SPP dengan cara membaca Barcode dengan Barcode reader dan bisa juga langsung digunakan sebagai kartu anggota perpustakaan, sedangkan Webcam berfungsi untuk mengambil foto siswa secara langsung untuk di tampilkan di kartu siswa, sehingga untuk membuat kartu siswa tidak perlu menyerahkan foto, selain itu foto yang diambil akan di simpan di database dengan type image sehingga dapat menghasilkan arsip data siswa lengkap dengan fotonya.

Berdasarkan uraian pada latar belakang diatas, rumusan masalah dalam penelitian ini adalah 1) bagaimana rancang bangun Sistem Informasi Akademik Berbasis Teknologi Barcode dan Webcam? 2) bagaimana implementasi Sistem Informasi Akademik Berbasis Teknologi Barcode dan Webcam?

Tujuan yang ingin dicapai dari penelitian ini adalah untuk mengetahui cara merancang suatu Sistem Informasi Akademik Berbasis Teknologi Barcode dan Webcam dengan mengimplementasikan teknik pengolahan basis data yang diolah dengan menggunakan Bahasa Pemrograman Visual Basic 6.0 dan database SQL Server. 
Manfaat yang ingin diambil dalam penelitian ini adalah agar sistem ini bisa digunakan oleh pihak SMA dalam hal ini SMA Negeri 1 Singaraja untuk mengelola sistem akademik sehingga dapat meningkatkan kenerja dari sistem itu sendiri. Sedangakan bagi penulis, hal ini bisa digunakan untuk menambah wawasan dan ilmu pengetahuan dalam merancang suatu sistem informasi yang terintegerasi dengan Barcode System dan webcam.

\section{KAJIAN TEORI}

Secara umum sistem yang terdapat di SMA terdiri dari sistem registrasi siswa baru, pembagian wali kelas, dan proses penawaran mata pelajaran, setelah terdaftar menjadi siswa maka secara otmatis siswa akan mendapatkan nomor induk siswa yang menjadi kode unik pada setiap siswa, setelah terdaftar menjadi siswa akan dilanjutkan dengan proses pembagian kelas sehingga proses belajar mengajar bisa dimulai.

Pada setiap siswa harus memiliki kartu siswa yang didapatkan dari sekolah, kartu siswa ini berfungsi sebagai tanda pengenal bahwa anak tersebut adalah seorang siswa, dalam penerapan Sistem Informasi Akademik Berbasis Teknologi Barcode dan Webcam kartu siswa dapat digunakan sebagai tanda pengenal saat pembayaran SPP atau kartu anggota perpustakaan. Proses selanjutnya adalah proses akademik yaitu masalah penilaian yang dilakukan pada masing-masing guru bidang studi, diakhir semester guru bidang studi akan merekap nilai sebagai laporan hasil belajar pada tiaptiap semster.

Sesungguhnya yang dimaksud dengan sistem informasi tidak harus melibatkan komputer. Sistem informasi yang menggunakan komputer bisa disebut Sistem Informasi yang Berbasis Komputer (Computer Based Information Systems) CBIS. Dalam prakteknya, istilah sistem informasi sering dipakai tanpa embel-embel berbasis komputer walaupun dalam kenyataannya komputer merupakan bagian yang penting. Sistem infomasi mencakup sejumlah komponen (manusia komputer, teknologi informasi, dan prosedur kerja) dan dimaksudkan untuk mencapai suatu sasaran atau tujuan (kadir,2003).

JPTK, UNDIKSHA, Vol. 7, No. 1, Januari 2010 : 41 - 52 
Istilah teknologi informasi (informations technology atau TI) mulai populer di akhir dekade 70-an. Pada masa sebelumnya, istilah teknologi komputer atau pengolahan data elektonis atau PDE (Elektrinic Data Procecing atau EDP).

Istilah teknologi sering kali rancu dengan istilah sistem informasi itu sendiri dan kadang menjadi bahan perdebatan. Ada yang menggunakan istilah teknologi informasi untuk menjabarkan sekumpulan sistem informasi, pemakai, dan manjemen (turban, McLean dan Wetherbe,1999). Pendapat ini menggambarkan teknologi dalam perspektif yang luas.

Menurut kamus Oxford (1995), teknologi informasi adalah studi atau penggunaan perlatan elektronika, terutama komputer, untuk menyimpan menganalisa, dan mendistribusikan informasi apa saja, termasuk kata-kata, bilangan, gambar.

Teknologi informasi mencakup keras dan perangkat lunak untuk melaksanakan satu atau sejumlah tugas pemrosesan seperti menangkap, mentransmisikan, menyimpan, mengambil, memanipulasi atau menampilkan data. (Alter,1992). Teknologi informasi tidak hanya terbatas teknologi komputer (perangkat keras dan perangkat lunak) yang digunakan untuk memproses dan menyimpan informasi, melainkan juga mencakup teknologi komunikasi untuk mengirmkan informasi (Martin,1999). Teknologi informasi adalah segala bentuk teknologi yang diterapkan untuk memproses dan mengirimkan informasi dalam bentuk elektronis (Lucas, 2000).

\section{METODE DAN PROSEDUR PENELITIAN}

Kegiatan penelitian ini merupakan pengembangan perangkat lunak, bukan penelitian eksperimen maupun penelitian tindakan. Sasaran akhir yang diharapkan adalah menghasilkan rancangan dan implementasi Sistem Informasi Akademik Berbasis Teknologi Barcode dan Webcam. Tempat untuk melakukan survey dan pencarian data yang digunakan sebagai acauan untuk merancang Sistem Informasi Akademik Berbasis Teknologi Barcode dan Webcam ini dilakukan pada SMA Negeri 1 Singaraja yang beralamat di Jalan Pramuka Singaraja 


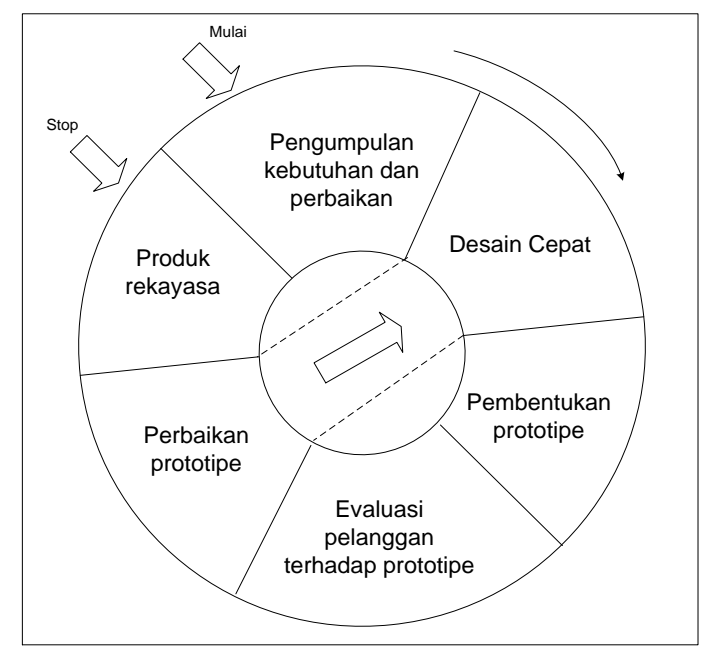

Gambar 1 Paradigma Prototyping

Pengembangan perangkat lunak Sistem Informasi Akademik Berbasis Teknologi Barcode dan Webcam ini mengikuti metodologi pengembangan perangkat lunak yaitu paradigma prototyping. Paradigma prototyping meliputi enam tahapan yaitu :

- Pengumpulan Kebutuhan dan Perbaikan

Pada tahap ini dilakukan pengumpulan kebutuhan perangkat lunak yang akan dibangun yang meliputi pendataan kebutuhan, data mana yang sudah tersedia, serta data mana yang perlu dikaji lebih jauh. Implementasi kegiatan pada tahap ini meliputi studi literatur, diskusi dan observasi.

- Desain Cepat

Hasil pada tahap pengumpulan kebutuhan kemudian dimanfaatkan sebagai data awal untuk mendesain spesifikasi global dari produk yang hendak dihasilkan. Tahap ini lebih terfokus pada aspek-aspek produk yang akan dimunculkan pada bagian tampilan.

- Membangun prototipe

Desain awal yang sudah dihasilkan selanjutnya diimplementasikan untuk mendapatkan simulasi dari hasil akhir yang diinginkan. Pekerjaan pada tahap ini belum menyentuh aspek detail dari produk yang dibangun dan lebih difokuskan untuk mempermudah pemahaman terhadap proses. 
- Evaluasi prototipe

Tahap ini dilakukan validasi dari nara sumber yang relevan yakni : pakar perpustakaan (pustakawan) dan pakar bidang pemrograman. Koreksi dari dari komponen ini akan dijadikan dasar perbaikan sistem sehingga dapat dihasilkan produk yang lebih bagus.

- Perbaikan prototipe

Kekurangan-kekurangan yang didata dari hasil evaluasi terhadap desain cepat selanjutnya digunakan sebagai masukan untuk melakukan revisi pada desain cepat. Siklus yang meliputi desain cepat, membangun prototipe, evaluasi prototipe oleh pengguna, dan perbaikan prototipe kemungkinan berulang lebih dari sekali sampai diperoleh sistem yang sesuai.

- Rekayasa produk

Hasil desain cepat yang disepakati antara pengembangan dengan pengguna selanjutnya digunakan sebagai acuan dalam pengembangan perangkat lunak riil yang nantinya akan digunakan.

\section{HASIL DAN PEMBAHASAN}

Sistem informasi akademik pada sebuah sekolah merupakan sistem yang dapat memberikan kemudahan-kemudahan dalam proses pengarsipan data guru, pengarsipan data mata pelajaran, pengarsipan data wali kelas, pengarsipan data tugas mengajar dan pengarsipan data nilai. Dengan sistem informasi ini kita bisa memberikan layanan informasi secara cepat karena semua informasi tersimpan didalam basisdata. Sistem informasi akademik ini terdiri dari beberapa fitur :

1. $\operatorname{login}$

2. master data

3. layanan siswa

4. pembuatan laporan

5. Tools

Struktur menu dari sistem informasi Akademik tingakat tingkat sekolah menengah atas terlihat seperti gambar dibawah 


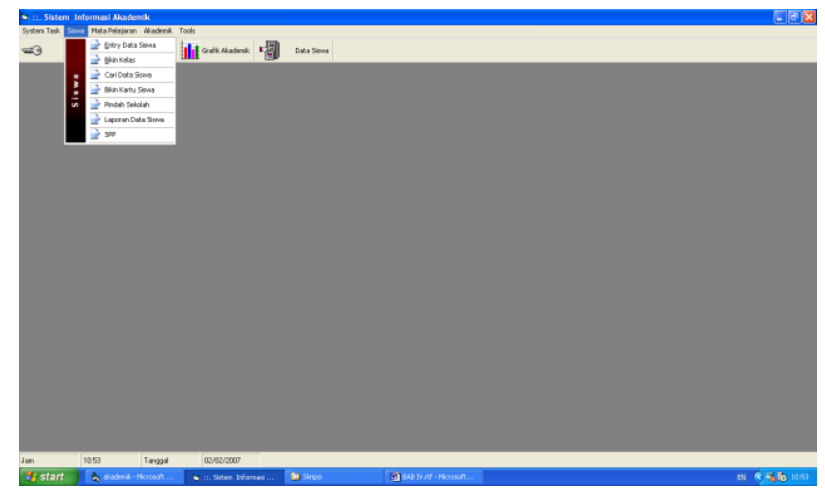

Gambar 2 Struktur menu

\subsection{Login}

Proses login merupakan langkah pertama yang harus dilakukan untuk dapat menggunakan sistem informasi ini, untuk dapat mengunakan sistem ini kita harus mendaftar sebagai user. Pada sistem ini terdapat dua tipe user yaitu administrator dan operator.

Administrator adalah user yang bisa mengakses semua fasilitas yang tedapat pada sistem sedaangkan operator adalah user yang hanya bisa mengakses fasilitas-fasilitas tertentu yang ada pada sistem. Seorang user akan mempunyai nama user dan password. Untuk login seorang user akan memasukkan nama user dan password kemudian menekan tombol "Login". Jika password dan user tidak terdaftar atau salah menuliskan password maka sistem akan memberikan pesan invali login. Proses ini ditunjukkan pada Gambar 4.2 dibawah

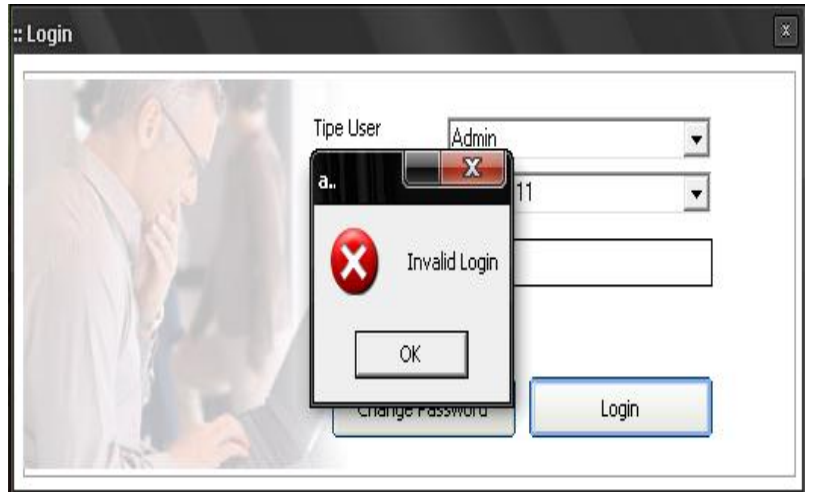

Gambar 3 Tampilan login 


\subsection{Masterdata}

Pada modul masterdata ini seorang admin bisa melakukan penambahan, pengubahan dan penghapusan data-data master. Data master ini berupa data Siswa, data guru dan pegawai, data mata pelajaran, data wali kelas. Data master ini nantinya akan sangat diperlukan oleh modul-modul lainnya, karena data yang akan diproses bersumber pada data master.

\subsection{Siswa}

Pada menu siswa terdapat beberapa sub menu seperti: pembagian kelas yang berfungsi untuk membuat kelas baru dalam setiap semester, pencarian data siswa yang berfungsi untuk mencari data siswa jika diperlukan, membuat kartu siswa yang berfungsi sebagai kartu identitas yang digunakan pada saat pembayaran SPP, pindah sekolah dan pindahan yang berfungsi untuk mencatat siswa yang pindah maupun siswa pindahan dari sekolah lain, dan pembayaran SPP yang berfungsi untuk mencatat pembayaran SPP bagi para siswa.

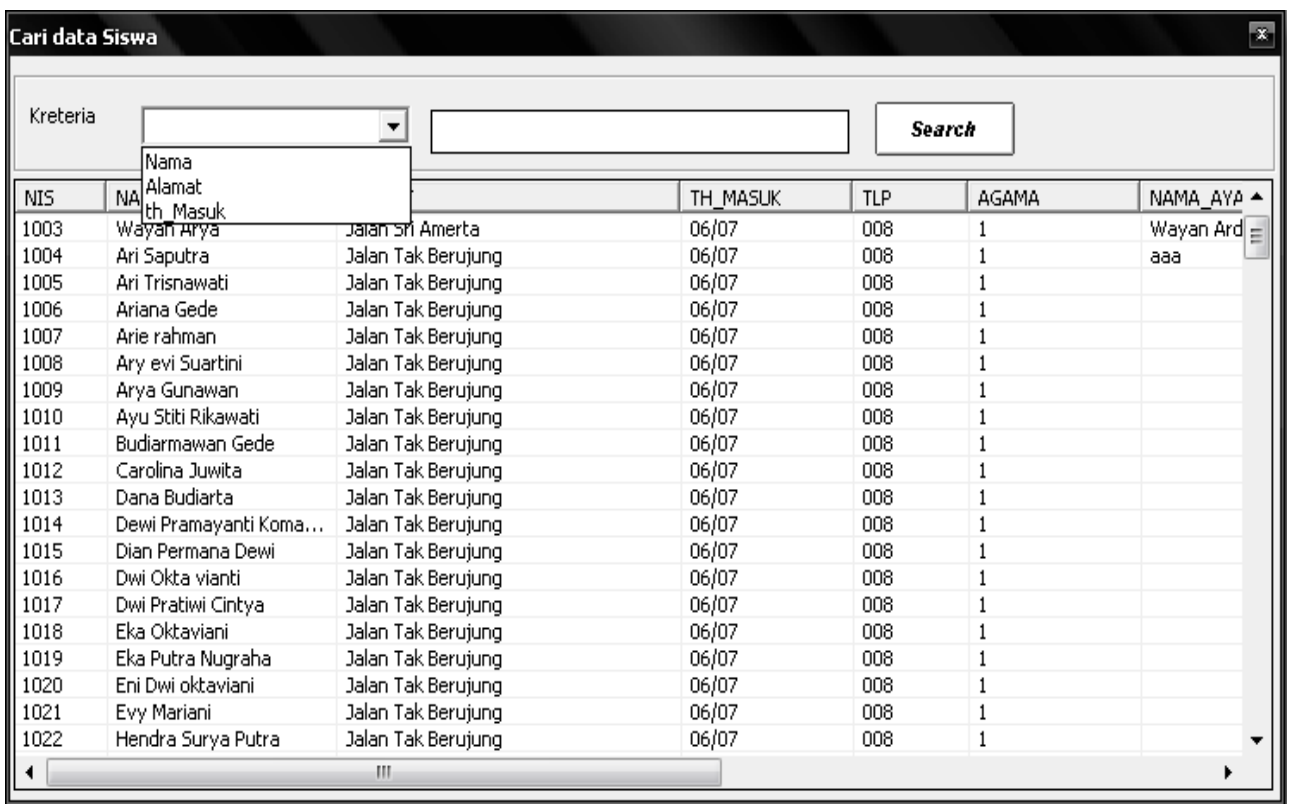

Gambar 4 Tampilan Proses Pencarian Data Siswa

Sistem Informasi Akademik Berbasis Teknologi Barcode..........(Kadek Surya Mahedy) 


\subsection{Laporan}

Pada menu laporan terdapat beberapa submenu sepeti: laporan data siswa yang berfungsi untuk memberian laporan jumlah siswa perkelas, laporan data guru dan pegawai yang berfungsi untuk mengetahui jumlah guru dan pegawai, laporan hasil belajar yang berfungsi untuk memberikan hasil belajar kepada para siswa dalam setiap akhir semester, laporan data wali kelas yang berfungsi untuk meberikan daftar wali dari masing-masing kelas, dan laporan tugas mengajar yang berfungsi untuk memberikan rekapan tugas mengajar masing-masing guru.

\section{DEPARTEMEN PENDIDIKAN NASIONAL SEKOLAH MENEGAH ATAS}

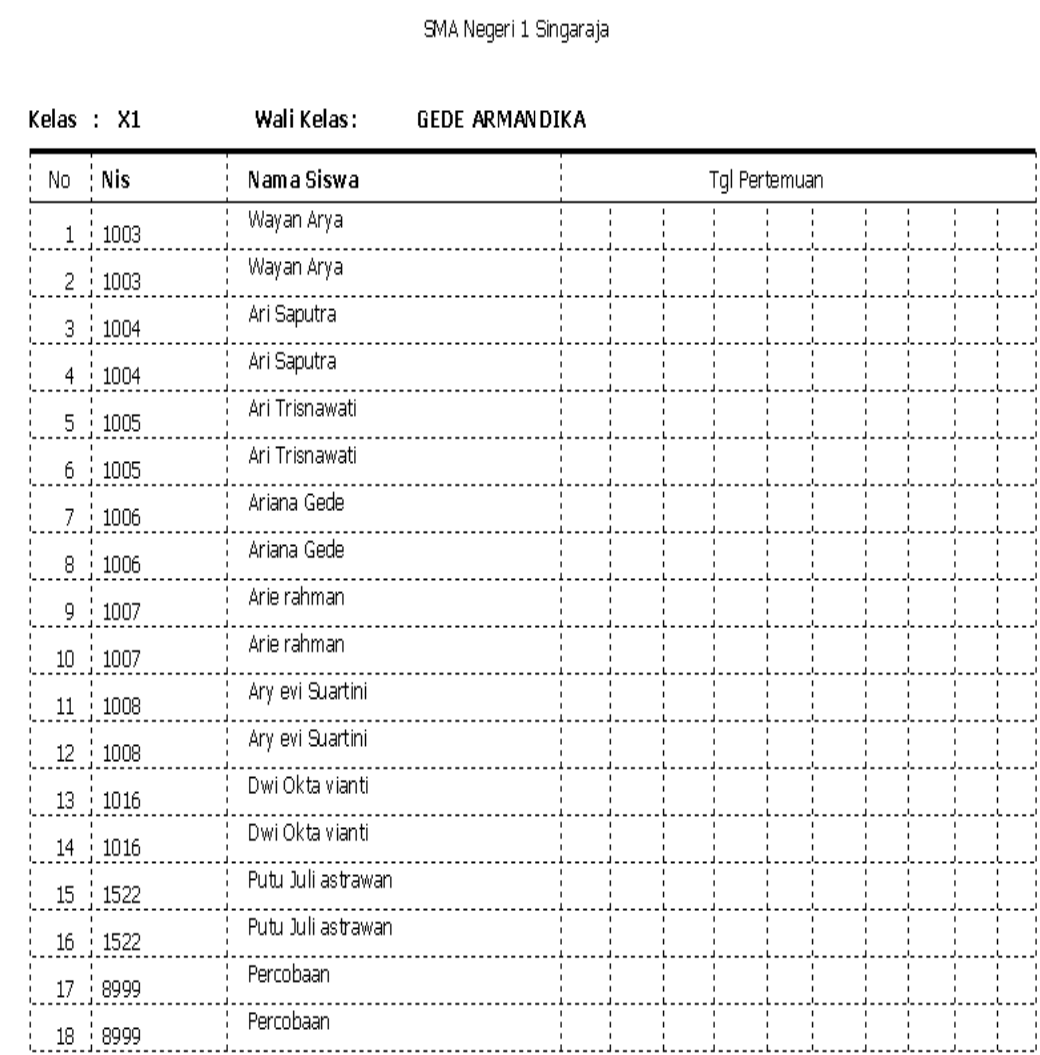

Gambar 5 Laporan Data Siswa 


\section{PENUTUP}

\section{Simpulan}

Berdasarkan hasil pengujian dan pembahasan yang dilakukan pada bab sebelumnya maka dapat dibuat kesimpulan:

1. Proses pencarian data siswa, guru dan pegawai bisa dilakukan dengan cepat sehingga dapat menghemat waktu pencarian.

2. Proses pencetakan laporan hasil belajar dapat dilakukan dengan cepat.

3. Mempermudah proses pengarsipan nilai siswa, sehingga mempermudah proses pengecekan jika terjadi kesalahan nilai.

4. Dapat mengarsipkan data siswa beserta foto siswa yang tersimpan di database.

5. Sistem informasi ini menyajikan laporan data siswa, data guru, data pelajaran dan data wali kelas.

\section{Saran-saran}

Saran-saran yang bisa dipertimbangkan untuk pengembangan aplikasi ini selanjutnya adalah:

1. Sistem ini belum menangani masalah kepegawaian dan penggajian sehingga perlu dikembangkan lebih lanjut.

2. Sistem ini akan lebih bagus jika digabungkan dengan sistem perpustakaan karena kartu siswa yang dihasilkan sudah menggunakan sistem barcode.

\section{DAFTAR PUSTAKA}

Bafadal Ibrahim. 2005. Pengelolaan Perpustakaan Sekolah. Jakarta. Bumi Aksara.

Evangelos Petroutsos. 2002. Menguasai Pemrograman Database Dengan Visual Basic 6. Jakarta. PT Elex Media Komputindo.

Fathansyah. 1999. Basis Data. Bandung. CV. Informatika.

Indrajit, Richardus Eko, 2000. Pengantar Konsep Dasar Manajemen Informasi dan Teknologi Informasi. Elex Media Komputindo. Jakarta.

Sistem Informasi Akademik Berbasis Teknologi Barcode..........(Kadek Surya Mahedy) 
Kadir A. 2002. Penuntun Praktis Belajar SQL. Yogyakarta. ANDI.

Kristanto H. 1994. Konsep dan Perancangan Database. Yogyakarta. ANDI.

M. Agus. J. Alam. 2000. Manajmen Database Dengan Microsoft Visual Basic Versi 6.0. Jakarta. PT Elex Media Komputindo.

Yuswanto.2001.Microsof Visual Basic 5.0 Untuk Pemrograman Multi User. Jakarta. Prestasi Pustaka. 